\title{
Contribution of Academic Self Concept and Locus of Control to The Learning Habits
}

\author{
Afni Rizkah Pulungan ${ }^{1}$, Marjohan ${ }^{2}$ \\ 1,2 Universitas Negeri Padang \\ *Corresponding Author: afnirizkahp@gmail.com
}

\begin{abstract}
This research was motivated by the low learning habits of students in school. The concept of academic self and locus of control are factors that are thought to influence learning habits. This study aims to illustrate the contribution of academic self-concept and locus of control to the learning habits of students in school. This research uses descriptive quantitative methods. Samples in this study 162 students selected using proportional random sampling techniques The instruments used in this study were likert scales on variables of academic self-concept and learning habits, on locus of control variables using internal-external inventory Rotters locus of control (I-E) scales. The findings of this study show that: (1) the average academic self-concept is in a moderate category, (2) locus of control is also in the high category, (3) learners' learning habits are categorized well, (4) academic self-concept contributes to learning habits by $36.3 \%$, (5) Locus of control contributes to learning habits by $10.6 \%$, and (6) academic self-concept and locus of control together contribute $36.4 \%$ to learners' learning habits. The study findings show that: (1) on average, academic self-concept is in the high category, (2) locus of control in the internal category, (3) learners' learning habits in the good category, (4) academic self-concept contributes to learning habits, (5) locus of control does not contribute to learning habits, and (6) academic self-concept contributes to learners' learning habits, and internal locus of control does not contribute to learning habits because it already leads to locus of external control. The implications of the research results can be used as an analysis of the needs in guidance and counseling services at SMA Negeri 13 Padang.
\end{abstract}

Keywords: Academic Self Concepts, Locus of control, Learning Habits

How to Cite: Pulungan, A.R., Marjohan, M. (2021). Contibution of Academic Self Concept and Locus of Control to Learning Habits. International Journal of Applied Counseling and Social SciencesI. 2 (1): pp 80-87. DOI: https://doi.org/10.24036/005396ijaccs

\section{Introduction}

Learning a process of change in the human personality and the change is displayed in the form of improving the quality and quantity of behavior such as improving skills, knowledge, attitudes, habits, understanding, skills, thinking and other abilities (Hakim, 2002). Learning is the process of interacting learners with educators and learning resources in a learning environment. Learning is the assistance provided by educators in order to obtain knowledge and knowledge, mastery of skills and habits, and the formation of attitudes and beliefs in learners (learners). In other words, learning is a process to 
help learners to learn well, because the learning process is experienced by humans throughout life so that learning can become a habit for learners to have satisfactory results (Rahyubi, 2012).

Learning habits are learning routines that include learning activities such as repeating lesson materials, exams, training of lesson materials, and learning in a conducive environment. Learning habits refer to knowledge, learning strategies, learning methods and the ability to manage time to do academic tasks. Learning habits are also characterized by proper learning routines and with material explanations supported by a conducive learning environment. Thus, learning depends on the positive behavior of learners and acts positively in learning in order to achieve optimal learning outcomes, specifically to be accepted in college (Crede \& Kuncel, 2008). Learning habits are also defined as techniques such as summarizing, noting, finding lesson materials to help complete tasks in learning, efficient learner learning habits have good learning methods as well as sedentary behaviors in learning (Rani, 2013).

The habit of learning is the behavior of a person who has been embedded for a relatively long time so that it characterizes the learning activities he does. Factors that influence the learning habits of learners are also very diverse. These factors can come from within the learner or from the student environment. In fact, these factors can be manipulated into positive learning habits (Aunurrahman, 2012). One of the keys in achieving satisfactory learning outcomes is that someone who wants to succeed in learning should have a good attitude and way of learning. A person's learning habits will affect his learning outcomes and he will have the right way of learning to obtain good learning outcomes or achievements (Hamalik, 2004).

Based on research in Nigeria revealed the achievements of learners depending on their own personal and also learning habits especially reading habits, which they have done on some chemistry lessons. This is because learners understand their ability to operate during laboratory discussions. (Tunde, Okay, \& Nature, 2010).

Another study in agricultural science explained the percentage of time in learning from 34 people in learning obtained an average of 35.8 percent who used 40 minutes of study, 25 respondents on average $26.3 \%$ who used 2 hours in study, 17 respondents got an average of $27.9 \%$ who used 6 hours in study, and 19 respondents got an average of $20 \%$ who used 3 hours in learning, this is seen the learning habits of students who are still lacking in the use and effective sharing of time in learning, so that the learning outcomes of students are low in school (Akpan, Salome, Harcourt, \& State, 2015).

The problem of poor learning habits of students is also a common concern at the international level, in this research journal states that $59 \%$ of educators are not satisfied with the ability of students in completing tasks given by teachers. The main weaknesses of the students include: lack of general knowledge, difficulty determining questions, inability to follow the learning process, processing information, and difficulty evaluating problems so as to affect students' poor learning habits. Problems regarding the learning habits of learners are also a concern of students and parents in Indonesia (Ingatius G, Rachmat D, and Praharesti E, 2013).

This was supported by research at SMK Negeri 2 Sungai Penuh in 2013 by interviewing 3 subject teachers revealed that learners are difficult to manage, when reprimanded they do not care. When students are not paying attention seriously, fussing, going in and out of class, students do not make Homework, cheat on tasks, even cheat during exams. In addition, students often say dirty, mock friends, even lack respect for teachers.Furthermore, interviews conducted with 5 learners revealed that when attending lessons in the classroom students do not want to ask questions to the teacher, students reasoned fear of being wrong, mocked or laughed at by their friends. In addition, students are less fond of certain subjects, and less like some teachers they take too seriously and are grumpy (Niko Reski, Taufik, Ifdil 2017).

Combs et al (Burns, 1979) also explained that students who have a low academic self-concept tend to produce low achievement or low grades, and tend to express themselves negatively, so it can be drawn that their learning habits are also not good.Students who have a high academic self-concept enjoy accepting challenges, taking risks, trying something new and also making some cognitive 
strategies, completing difficult academic tasks and setting higher academic goals, as well as academically high performance Bong et al (Villegas, 2013).

The Locus of control is a concept put forward by Julian F.Rotter (1966) which explains the extent to which individuals believe that their behavior determines what will happen to them. He asserts that the quality or degree of a person controlling various events in his life will influence the decisions he will make and his interactions with others (Marjohan, 2013). So that the characteristics of the learner's internal locus of control include a full attention to something, competent, able to resist and overcome influences from outside, achievement-oriented, deft, and believe in one's own abilities so that he should have good learning habits.

The internal locus of control is positively related to the academic achievement of learners, the results of which show that people with an internal locus of control tendency will be effective in the learning process thus showing a higher score of achieving success than fate-oriented learners and luck or external locus of control (Walker, 2001). In this study there is a positive relationship of academic self-concept with academic achievement, and internal locus of control with academic achievement, this is certainly related to effective learning in the classroom. The concept of high academic self has high academic achievement supported by a good locus of control, and vice versa (Robert C.Kanoy, 1980).

Based on the explanation above, it can be concluded that students must have good learning habits in school so that they feel optimistic and confident in their ability to succeed in learning. As for the impact when not having good learning habits learners will not be active in learning activities, do not have a commitment in learning, are not sure of their abilities, and learners will violate the rules in the learning process activities. Therefore, it is necessary to implement guidance and counseling services in schools that are more optimal to foster and improve the concept of academic self, locus of control, and learning habits of learners. On that basis. Then it is necessary to do scientific research.

\section{Method}

This research method uses kuantitaif with descriptive types of correlational simple regression and double regression. The study population was 273 students of SMA Negeri 13 Padang, a study sample of 162 people selected with propotional random sampling techniques. The instruments used in this study were likert scales on variables of academic self-concept and learning habits, on locus of control variables using internal-external inventory Rotters locus of control (I-E) scales. Scale used by two types because the locus of control is the instrument adopted. Data analysis with descriptive stastistics, simple regression and double repression. Data analysis is assisted by using SPSS 20.00 program. The analysis requirements performed on this research data are normality test, linearity test, and multicollinierity test.

\section{Results}

Data in this study includes variables of academic self concept (X1), locus of control (X2) and learning habits $(\mathrm{Y})$. The following is presented a description of the data of the research results.

\section{Academic Self Concept (X1)}

Description of academic self concept data can be seen in Table 1 
Table 1. Distribution of Frequency and Percentage of Academic Self Concepts

\begin{tabular}{cccc}
\hline Interval Score & Category & Frequency & $\%$ \\
\hline$\geq 137$ & Very high & 3 & 2 \\
$118-136$ & High & 28 & 17 \\
$99-117$ & Medium & 75 & 46 \\
$80-98$ & Low & 52 & 32 \\
$\leq 79$ & Very low & 4 & 3 \\
& Total & 162 & 100 \\
\hline
\end{tabular}

Based on Table 1 above, showing that most students have academic self-concept in a moderate category of $46 \%$, some students are in a high category of $17 \%$, then some students in the very high category are $2 \%$. So on average the academic self-concept of learners is in a moderate category. This means that the average learner has a good academic self concept.

\section{Locus of Control $\left(\mathrm{X}_{2}\right)$}

Description of Locus of control data seen in Table 2.

Table 2. Distribution of Frequency and Percentage of Locus of Control

\begin{tabular}{|c|c|c|c|}
\hline Interval Score & Category & Frequency & $\%$ \\
\hline$\geq 11,5$ & Internal & 57 & 64.815 \\
\hline$\leq 11,5$ & External & 105 & 35.185 \\
\hline \multicolumn{2}{|c|}{ Total } & 162 & 100 \\
\hline
\end{tabular}

Based on Table 2 above, shows that the majority of internal locus of control learners are $64.815 \%$, higher, and some learners in the locus of external control category are lower at $35.185 \%$. On average, the internal locus of control is in a higher category than the external locus of control. This means that the average learner has a high locus of internal control.

\section{Learning Habits (Y)}

Description of Learning Habits data can be seen in Table 3.

Table 3. Distribution of Frequency and Percentage of Learning Habits

\begin{tabular}{|c|c|c|c|}
\hline Interval Score & Category & Frequency & $\%$ \\
\hline$\geq 245$ & Very good & 9 & 5 \\
\hline 217-244 & Good & 34 & 21 \\
\hline $189-216$ & Pretty good & 61 & 38 \\
\hline $161-188$ & Not good & 52 & 32 \\
\hline$\leq 160$ & Very Bad & 6 & 4 \\
\hline \multicolumn{2}{|c|}{ Total } & 162 & 100 \\
\hline
\end{tabular}

Based on Table 3 above, shows that most students have good learning habits of $38 \%$, some students in the good category are $21 \%$, then in the excellent category $5 \%$. So on average the learning habits of learners are in a pretty good category. This means that students have good learning habits in the learning process at home and at school.

The analysis requirements performed on this research data are normality test, linearity test, and multicollinierity test.

Description of normality test data can be seen in Table 4 . 
Table 4. Normality Test Results

\begin{tabular}{cccc}
\hline Variabel & Asymp. Sig & Significance & Description \\
\hline $\mathbf{X}_{\mathbf{1}}$ & 0.488 & & Normal \\
$\mathbf{X}_{2}$ & 0.193 & 0.05 & Normal \\
$\mathbf{Y}$ & 0.873 & & Normal \\
\hline
\end{tabular}

Based on Table 4 above, all three variables have Asymp's score. Sig. greater than the specified significance (0.05). That is, the data from the three variables is distributed normally.

Description of linearity test data can be seen in Table 5.

Table 5. Linearity Test Results

\begin{tabular}{ccccc}
\hline Variable & Fhitung & Ftabel & Sig. & Description \\
\hline $\mathbf{X}_{1} \mathbf{Y}$ & 0.601 & 3,90 & 0.981 & Linear \\
$\mathbf{X}_{2} \mathbf{Y}$ & 0.929 & 3,90 & 0.536 & Linear \\
\hline
\end{tabular}

Based on Table 5 above show that the academic self-concept variables (X1) and Locus of control (X2) against learning habits $(\mathrm{Y})$ are greater than the predetermined significant $(0.05)$. This means that the data of each variable $X$ is linear. If the value is sig. deviation from liearity $>0.05$, then the data is declared linear.

Description of multicolinearity test data can be seen in Table 6

Table 6. Multicolinearity Test Results between Academic Self Concept (X1) and Locus of Control (X2)

\begin{tabular}{cccc}
\hline Variable & Tolerance & VIF & Description \\
\hline (Constant) & & & No \\
$\mathbf{X}_{1}$ & 1,000 & 1,001 & multicollinierity \\
$\mathbf{X}_{2}$ & 1,000 & 1,001 & occurred \\
\hline
\end{tabular}

Based on Table 6 above, if variance inflation factor (VIF) value is $<1,000$ then it means that there is no multicolinearity and vice versa if variance inflation factor (VIF) value is $>1,000$ then it means multicollinierity. It refers to the basis of decision making in multicolloremity testing that there is no multicollitasity between the concept of academic self and the locus of control.

Table 7. Results of The Regression Coefficient Test of Academic Self Concept (X1) on Learning Habits (Y), and Result of Locus of Control Regression Coefficient Test (X2) on Learning Habits (Y)

\begin{tabular}{ccc}
\hline Variabel & $\mathbf{R}$ & $\mathbf{R}$ Square \\
\hline $\mathbf{X}_{1-Y}$ & 0.603 & 0.363 \\
$\mathbf{X}_{2-} \mathbf{Y}$ & 0.002 & 0.000 \\
\hline
\end{tabular}

Based on Table 7 above shows that the value of $\mathrm{R}$ is 0.603 , which indicates the coefficient of regression of academic self-concept to learning habits. $R$ Square (R2) value of 0.363 , meaning $36.3 \%$ of the contribution of academic self-concept to learning habits. Based on Table 7 above shows that the value of $R$ is 0.002 which indicates the coefficient of regression locus of control against learning habits. The R Square (R2) is 0.000 , which means $0.000 \%$ of the locus of control contribution to learning habits.

Table 8. Results of Double Regression Coefficient Test academic self concept (X1) and Locus of control (X2) on Learning Habits (Y)

\begin{tabular}{ccc}
\hline Variable & $\mathbf{R}$ & $\mathbf{R}$ Square \\
\hline $\mathbf{X}_{1} \mathbf{X}_{2}-\mathbf{Y}$ & 0.603 & 0.363 \\
\hline
\end{tabular}


Based on Table 8 above shows that the value of $\mathrm{R}$ is 0.603 , which indicates the coefficient of double regression of academic self-concept and locus of control over learning habits.Square's R score is 0.364, which means $36.3 \%$ of academic self-concepts and locus of control are jointly against learning habits.

\section{Discussion}

\section{Contribution of Academic Self Concept to Learning Habits}

The results of research show that the concept of academic self contributes significantly to the learning habits of learners.This finding was obtained based on data analysis that the contribution of academic self-concept to the learning habits of learners amounted to $36.3 \%$. While the rest $(63.7 \%$ of the rest) described other variables. That is, the concept of academic self is one of the factors that contribute to learning habits.

Based on the results of the study, the learning habits of learners are also determined by the concept of academic self to form good and consistent learning habits at school and also at home.This is in accordance with Rauh's research (2013) that the concept of high academic self has characteristics such as (1) having confidence and ability to solve obstacles, (2) having the realization that the environment does not always support every sense, desire or behavior, (3) can change one's self for the better, (4) have self-confidence and (5) have a model of receiving respect without shame. So, overall students who have a high academic self-concept will tend to have the confidence to carry out all their academic activities. Furthermore, the description of this study explains that the concept of academic self is high, but the wider scope is not only limited in the process of academic activities of learners, but the concept of positive academic self has a correlation to the academic behavior of learners outside of learning activities. Such as repeating lessons at home, doing school assignments at home, and reading at leisure so that the habits of studying at school and at home (McCoach \& Siegle, 2003).

Good learner's academic self-concept will make it easier to do their learning activities so that their learning achievements will be good. However, students who are inconsistent in carrying out learning activities and do not have a good academic self concept tend to have no commitment in learning and will have difficulty in realizing learning habits at school and at home. Therefore, it is important for learners to improve the concept of academic self, so that students have good learning habits at school and at home.

\section{Contribution of Locus of Control to Learning Habits}

The results showed that locus of control did not contribute to the learning habits of learners. These findings were obtained based on data analysis that the contribution of locus of control to learners' learning habits by $0.000 \%$. While the rest $(100 \%)$ other variables are described. That is, locus of control is one of the factors that do not contribute to the learning habits of learners because the results obtained by the internal locus of control are already in the range between the internal and external locus of control. This means that students believe their learning habits are due to effort and also luck or fate factors.

In accordance with the opinion of Poulsen and Honnet (Hartanto, 2012) changes in age, experience in an institution, and exercise in the learning process are factors that influence changes in the locus of control externally and internally so it can be concluded that exercise factors in the learning process are the main causes of tendency locus of control is good.

Other factors that contribute to learning habits are healthy study habits and attitudes (SHAs) confirmed in this study there is a significant correlation between students' learning habits and attitudes and their performance in licensing exams. Thus, to improve the quality of education, there needs to be an increase in learning habits and attitudes of students.This can be done through the provision of development programs that will help students build efficient and effective learning habits and positive attitudes towards learning (Mendezebal, M.J.N., 2013). 


\section{Contribution of Academic Self Concept and Locus of Control to Learning Habits}

The results showed that academic self-concept contributed significantly to learners' learning habits but not to locus of control. This finding was obtained based on data analysis that the value of $\mathrm{R}$ Square (R2) is $36.3 \%$, this means that $36.3 \%$ of good or bad learning habits of learners are subjected to academic self-concept, while the rest $(63.6 \%)$ described by other variables.

Based on the findings above, it can be known that academic self-concept is a factor that influences students' learning habits. Academic self-concept is useful to improve the learning habits of students who are less committed and less involved in learning so as to improve their learning habits and can commit in learning to feel lighter in carrying out learning at school and at home.

\section{Conclusion}

Based on the findings and discussion of the results of the study, it can be put forward the following conclusions. (1) On average, the academic self-concept of students of SMA Negeri 13 Padang is in the high category. That is, students have confidence about academic competence, have a good perception of academic competence, have a high commitment to learning, and are involved in learning activities. (2) On average the locus of control of students at SMA Negeri 13 Padang is in the internal category but is between the internal locus of control range and the external locus of control. That is, students believe in their efforts but students also believe in the fate or luck they get. (3) On average, the category of learning habits of students at SMA Negeri 13 Padang is in the good category. This means that students can manage their time effectively, have good learning readiness, read student materials, follow learning well, dare to ask and answer during the learning process, do tasks independently, have a habit of practicing in learning, have good habits by learning before taking exams, and have a habit of reading resources about learning in order to enrich themselves (4) Academic self-concept contributes to the learning habits of students at SMA Negeri 13 Padang. That is, whether or not good learning habits can be explained by academic self-concept.It can be concluded that the higher the academic self-concept, the better the learning ability. (5) Locus of control does not significantly contribute to the learning habits of students at SMA Negeri 13 Padang.It means whether or not learners' learning habits can not be explained by locus of control.It can be concluded that, the locus of internal control is already leading to the external so it can not affect learning habits. (6) The concept of academic self and locus of control together do not contribute to the learning ability of students at SMA Negeri 13 Padang.It means good or not good learning habits of learners only influenced by one variable (academic self-concept), but locus of control does not affect learning habits. In other words, the higher the academic self-concept, the better or better the learning habits of learners. Locus of contol does not contribute because the locus of control of learners has led to an external locus of control, which means that learners believe in good learning habits due to their efforts and also luck or fate.

\section{References}

Akpan, N. A., Salome, E., Harcourt, P., \& State. R. (2015). Effect of study habit on academic achievement of agricultural science students in senior secondary school in emohua local government area of rivers state, Nigeria, 1(8), 118-125.

Aunurrahman. (2012). Belajar dan pembelajaran. Bandung: Alfabeta.

Burns, R.B. (1979). Konsep diri: teori, pengukuran, perkembangan, dan perilaku. Terjemahan oleh Eddy. Jakarta: Penerbit Arcan.

Crede, M., \& Kuncel, N. R. (2008). Study habits, skills, and attitudes, 3(6), 425-453.

Hakim, T. (2002). Belajar secara efektif. Jakarta: Puspa Swara.

Hamalik, Oemar (2004). Proses Belajar Mengajar. Jakarta: Bumi Aksara

Hartanto, Dody. (2012). Bimbingan dan konseling menyontek. Jakarta: Indeks 
Ingatius G, Rachmat D, dan Praharesti E. (2013). Bimbingan belajar efektif untuk meningkatkan kebiasaan belajar, vol 1, no 2 .

Marjohan. (2013). Pengembangan internal locus of control dalam pelayanan konseling dan implikasinya terhadap perbedaan budaya klien, 1 Nomor 2, 136-142.

Mendezabal, M. J. N. (2013). Study habits and attitudes: the road to academic success. University of saint Louis, Cagayan

Niko Reski, Taufik, I. (2017). Konsep diri dan kedisiplinan belajar siswa, Volume 3 N(1999), 85-91.

Robert C.Kanoy. (1980). Locus of control and self concept in achieving and underachieving bright elementary students, (1968), 395-399.

Rahyubi Heri. (2012). Teori-teori belajar dan aplikasi pembelajaran motorik. Bandung: Nusa Media.

Rani. R. (2013). Relationship between home environment and study habit of senior secondary school students, $2(7), 38-42$.

Rauh, I. Y. (2013). Kontribusi kompetensi profesional guru, konsep diri akademik serta motivasi kerja guru terhadap kinerja guru matematika di tingkat SMA se-kabupaten karangasem. Jurnal Penelitian Pascasarjana Undiksha, (4), 1-14.

Siegle, D., McCoach, B. (2003). The structure and function of academic self-concept in gifted and general education students. Roeper Review, 25(2), 61-65.

Tunde, O., Oke, O. K., \& Alam, G. M. (2010). An investigation into student study habit in volumetric analysis in the senior secondary provision: A case study in Ondo State, Nigeria, 4(June), 324-329.

Villegas, G. O., Tomasini, G. A., dan Lagunes, L. I. R. (2013). Development of an academic self concept for adolescent (ASCA) SCALE. Journal of behavior, health, and sociL issues, 5: 117-130.

Walker, J. (2001). Control and the psychology of healt theory, measurement and applications. Philadelpia: Open University Press. 